SPOR BILIMLERİ ARAŞTIRMALARI DERGISİ
Journal of Sport Sciences Researches
JSSR
http://dergipark.gov.tr/jssr
ISSN: $2548-0723$

\title{
Rekreasyon Bölümü Öğrencilerinin Boş Zaman Yönetimi ile Akademik Başarılarını Etkileyen Örgütsel Faktörler Arasındaki İlişkinin İncelenmesi*
}

\author{
Fatih YAŞARTÜRK ${ }^{1 \dagger}$, Hayri AKYÜZ², İsmail KARATAŞ⿻ ${ }^{3}$ \\ ${ }^{1}$ Bartın Üniversitesi, BESYO, Beden Eğitimi ve Spor Öğretmenliği Bölümü, https://orcid.org/0000-0003-4934-101X \\ ${ }^{2}$ Bartın Üniversitesi, BESYO, Rekreasyon Bölümü, https://orcid.org/0000-0002-8550-6689 \\ ${ }^{3}$ Bartın Üniversitesi, BESYO, Beden Ĕ̈itimi ve Spor Öğretmenliği Bölümü, https://orcid.org/0000-0002-1237-4670
}

$\ddot{\mathbf{O} z}$

Orijinal Makale

Bu araştırmanın amacı rekreasyon bölümü öğrencilerinin boş zaman yönetimi ile akademik başarılarını etkileyen örgütsel faktörler arasındaki ilişkinin bazı demografik değişkenlere göre incelenmesidir. Araştırmaya, Bartın Üniversitesi Beden Eğitimi ve Spor Yüksekokulu Rekreasyon Bölümünde öğrenim gören 309 (196 erkek ve 113 kadın) kişi katılmıştır. Veri toplama aracı olarak, araştırmacılar tarafindan hazırlanan kişisel bilgi formu, Wang, Kao, Huan ve Wu (2011) tarafindan geliştirilen ve Türkçe uyarlaması Akgül ve Karaküçük (2015) tarafından yapılan "Boş Zaman Yönetimi Ölçeği (BZYÖ)" ve Memduhoğlu ve Tanhan (2013) tarafından geliştirilen "Öğrencilerin Akademik Başarılarını Etkileyen Örgütsel Faktörler Ölçeği (ÖBEÖFÖ)" Verilerin analizinde, katılımcıların demografik özelliklerine göre, boş zaman yönetimi ve akademik başarı düzeyleri arasındaki farklılıkları incelemek amacıyla tTesti ve ANOVA, değişkenler arasındaki ilişkilerin incelenmesi için ise Pearson Korelasyon analizi uygulanmıştır. Araştırmanın bulgularında, t-Testi sonuçlarında "cinsiyet" değişkenine göre ÖBEÖFÖ toplam puanlarında anlamlı farklılık olduğu görülmektedir $(p<0,05)$ ve bu farklılık erkek öğrencilerin lehinedir. Korelasyon testi sonuçlarında "yaş" değişkenine göre BZYÖ ve ÖBEÖFÖ toplam puan ortalamaları arasında anlamlı bir ilişki bulunmamıştır $(\mathrm{p}>0,05)$. Diğer taraftan, ANOVA testi sonuçlarında "sınıf" değişkenine göre BZYÖ ve ÖBEÖFÖ toplam puanlarında anlamlı farklılık tespit edilmiştir $(\mathrm{p}<0,05)$. Ek olarak "rekreatif etkinliklere katılma" değişkenine göre BZYÖ ve ÖBEÖFÖ toplam puanlarında anlamlı farklılık saptanmıştır $(\mathrm{p}<0,05)$ ve bu farklılığın faaliyetlere katılan grubun lehinedir. Korelasyon testi sonucunda "gelir" değişkeni ile BZYÖ "boş zaman tutumu" alt boyutunda pozitif yönde ve düşük düzeyde anlamlı bir ilişki bulunmuştur $(p<0,05)$. Son olarak, BZYÖ ve ÖBEÖFÖ toplam puan ortalamaları arasında pozitif yönde ve düşük düzeyde anlamlı bir ilişki olduğu belirlenmiştir $(p<0,05)$. Sonuç olarak, katılımcıların boş zaman yönetimi ve akademik başarı düzeylerinin cinsiyet, sınıf, rekreatif etkinliklere katılma gibi değişkenlere göre farklılık gösterdiği; BZYÖ ve ÖBEÖFÖ arasında pozitif yönde düşük düzeyde bir ilişkinin olduğu ve katılımcıların boş zaman yönetimini olumlu ve doğru bir şekilde yapması durumunda akademik başarı düzeylerinin de olumlu yönde artacağı söylenebilir.

\author{
Anahtar kelimeler: \\ Rekreasyon bölümü ögrencileri, \\ boş zaman yönetimi, \\ akademik başarı.
}

*Bu çalışma 13-15 Nisan 2018 tarihlerinde Antalya/Alanya şehrinde gerçekleştirilen Uluslararası Herkes İçin Spor ve Wellness Kongresi'nde bildiri olarak sunulmuştur.

† Sorumlu Yazar: Fatih YAŞARTÜRK, E-mail: fatihyasarturk@gmail.com, Tel: +905554995348 
Yaşartürk, F., Akyüz, H., ve Karataş, İ. (2018). Rekreasyon bölümü öğrencilerinin boş zaman yönetimi ile akademik başarılarını etkileyen örgütsel faktörler arasındaki ilişkinin incelenmesi. Spor Bilimleri Araştırmaları Dergisi, 3(2), 233-243.

\title{
The Investigation of the Relationship Between Recreation Department Students' Organizational Factors Affecting Their Academic Achievement and Leisure Management
}

\begin{abstract}
The purpose of this research is to examine relationship between recreation department students' organizational factors affecting their academic achievement and leisure management according to some demographic variables. 309 (196 men and 113 women) people studying at Bartın University School of Physical Education and Sports Recreation Department participated in the research. As a data collection tool, prepared by researchers "Personal Information Form", developed by Wang, Kao, Huan, \& Wu (2011) and Turkish adaptation was made by Akgul and Karakucuk (2015) "Leisure Management Scale: LMS" and developed by Memduhoglu ve Tanhan (2015) "Scale of Organizational Factors Affecting Student Academic Achievement: SOFASAA" were used. In the analysis of the data; according to the demographic characteristics of the participants, t-test and ANOVA were applied to investigate the differences between levels of academic achievement and leisure management, Pearson Correlation test was applied to examine relations between variables. In the findings of the research, there was a significant difference in the t-test results according to the "gender" variable in the SOFASAA total score avarages $(p<0,05)$ and this difference is in favor of male students. There was no significant relationship between LMS and SOFASAA total score averages according to "age" variables in the correlation test results $(\mathrm{p}>0,05)$. On the other hand, in the ANOVA test results, there was a significant difference between the LMS and SOFASAA total scores according to the "class" variable $(p<0,05)$. In addition, a significant difference was found in the total scores of LMS and SOFASAA according to the variable "participation in recreational activities" $(p<0,05)$ and this difference was found to be in favor of the group participating in the activities. In the correlation test results, there was a significant positive and low level relationship between the "income" variable with the LMS total scores and in the "leisure attitude" sub-dimension $(p<0,05)$. Finally, there was a significant relationship between the participants' mean scores of LMS and SOFASAA $(p<0,05)$. As a result, participants' leisure time management and academic achievement levels differed according to variables such as gender, class, participation in recreational activities; it has been determined that there was a significant positive and low level relationship between LMS and SOFASAA and it has been determined that the participants' level of academic achievement will increase in the positive direction if the participants do leisure management positively and correctly.
\end{abstract}

\section{GíRiș}

Zaman kavramı, insanın gelişiminde her zaman olan ve olmaya devam edecek bir kavramdır. İnsanların kişisel, toplumsal ve mesleki başarı elde etmesinde zaman kavramı her zaman en büyük rolü üstlenmiştir. Zaman insan hayatında olmazsa olmaz olan bir kavram olarak karşımıza çıkmakta ve insanın varoluşundan bugüne kadar en iyi değerlendirme yöntemleri zamanın kullanımı ile araştırılmıştır.

Zaman, herkesin eşit olarak sahip olduğu, fakat aynı şekilde kullanamadığı son derece değerli, eşsiz bir kaynaktır. Ama para gibi toplanamaz, hammadde gibi depolanamaz, bir pasta gibi başkasına ikram edilemez, bir araç gibi durdurulamaz, bir mal gibi kullanılamaz ve hiç bir şekilde yeri doldurulamaz. Belli sınırlar içinde, bir kaynağın yerine bir başkasını koyabiliriz, örneğin, insan gücü yerine makine kullanabiliriz. Ancak, zamanın yerini alabilecek başka hiçbir kaynak yoktur. O nedenle zaman eşittir yaşam denilebilir. Zamanı boşa geçirmek de yaşamı boşa geçirmek anlamına gelir (Adair, 2006; Sabuncuoğlu, Paşa ve Kaymaz, 2010). Zamanı iyi yönetmek ise bireysel anlamda; kariyeri daha iyi planlama ve geleceğe hazırlanma, daha fazla okuma ve öğrenme, yeni gelişmeleri ve teknolojiyi takip etme, aile ve diğer insanlara daha fazla zaman ayırma, dinlenme, eğlenme, düşünme, yeni fikirler yaratma, yeni projeler başlatmak için firsat sağlar (Sayan, 2005). Bu yüzden zamanın 
Yaşartürk, F., Akyüz, H., ve Karataş, İ. (2018). Rekreasyon bölümü öğrencilerinin boş zaman yönetimi ile akademik başarılarını etkileyen örgütsel faktörler arasındaki ilişkinin incelenmesi. Spor Bilimleri Araştırmaları Dergisi, 3(2), 233-243.

yönetimini iyi sağlayan insanlar başarıya ulaşmada engelleri rahat geçebilecek ve kendi hayat döngüsünün içindeki olumlu sonuçlara ulaşacaktır.

Günümüzde boş zaman anlayışındaki gelişim sürecinin gelişmiş ve sanayileşmiş ülkelerle, kısmen de olsa Türkiye gibi gelişmekte olan ülkelerde uygarlık ve gelişmişliğin bir nimeti olarak değerlendirilmesi şeklinde devam ettiği görülmektedir. Nitekim günlük ve haftalık çalışma saatlerindeki azalmalar ile tatil günlerinin çoğalması, toplumsal normlardaki değişim gibi nedenlerle boş zamanların sosyal ve toplumsal hayat içerisindeki önemi, daha da belirginleşmeye ve artmaya hızlı bir şekilde devam etmektedir. Bireylerin boş zamana sahip olmaları ve boş zamanlarında gerçekleştirdikleri faaliyetler, doğrudan veya dolaylı olmak kaydı ile hayatlarının diğer boyutlarını ve değerlerini de etkileyen bir durumdur. Bu durumu Karaküçük (2008), "Boş zamanları iki tarafı keskin bir kılıca benzetmek mümkündür." ifadesi ile özetlemektedir. Olumlu kullanılırsa, kişisel ve toplumsal gelişim, olumsuz kullanılırsa bunalım, başıbozukluk gibi problemler doğurabilmektedir. $\mathrm{Bu}$ durum da toplumun önemli bir kesimini oluşturan 'gençlik' için çok daha önemsenmesi gereken bir olguyu ortaya koymaktadır (Akgül ve Karaküçük, 2015).

Zamanın yönetimi etkin ve verimli kullanabilmek hem stresi ve kaygıyı azaltır hem de başarıya ulaşma ihtimalini arttırır. Zamanı etkili kullanabilmek için etkin bir program yapmak ve başarı kısasları belirlemek gerekir. Dolayısıyla başarıya ulaşmak için zaman yönetiminde etkili olmak önem arz etmektedir. Wolman'a (1973) göre başarı, "istenilen bir sonuca ulaşma yönünde bir ilerlemedir". Başarı bu kadar geniş kapsamlı tanımlanmakla birlikte eğitimde başarı denildiğinde genellikle okulda okutulan derslerde geliştirilen ve ögretmenlerce takdir edilen notlarla, test puanlarıyla ya da her ikisi ile belirlenen beceriler veya kazanılan bilgilerin ifadesi olan "Akademik Başarı" kastedilmektedir (Carter ve Good, 1973). Akademik başarı genellikle, öğrencinin psikomotor ve duyuşsal gelişiminin dışında kalan, bütün program alanlarındaki bilişsel davranış değişmelerini ifade eder (Ahmann ve Glock, 1971). Bununla birlikte okulda okutulan derslerle öğrencilerde sağlanması öngörülen davranış değişiklikleri bilişsel davranışlarla sınırlı değildir (Julian ve Stanley, 1972). Öğrencilerin akademik başarısında etkili olan çok sayıda faktörün olduğu bilinmektedir. Bunlardan bazıları, öğrencinin zihinsel kapasitesi, duyuşsal özellikleri, öğretim hizmetinin niteliği, öğrencinin sosyo-ekonomik durumu, öğretmen niteliği, sınıf ya da okul koşulları olarak siralanabilir (Bloom, 1979; Can, 1992, Jersild, 1983). Dolayısıyla üniversite öğrencilerinin genel başarı ve akademik başarı elde etmeleri için zaman yönetimi ve tekniklerini verimli şekilde kullanması gerekiyor. Ancak bu şekilde üniversite döneminde çalışmalar sonucunda akademik başarı olarak kendini gösterecektir.

$\mathrm{Bu}$ bilgiler dahilinde araştırmanın amacı, rekreasyon bölümü öğrencilerinin boş zaman yönetimi ile akademik başarılarını etkileyen örgütsel faktörler arasındaki ilişkinin bazı demografik değişkenlere göre incelenmesidir. 
Yaşartürk, F., Akyüz, H., ve Karataş, İ. (2018). Rekreasyon bölümü öğrencilerinin boş zaman yönetimi ile akademik başarılarını etkileyen örgütsel faktörler arasındaki ilişkinin incelenmesi. Spor Bilimleri Araştırmaları Dergisi, 3(2), 233-243.

\section{YÖNTEM}

\section{Araştırmanın Modeli ve Örneklemi}

Araştırmada, araştırma amaçlarına uygun olarak “Tanımlayıcı (Betimsel) ve İlişkisel Tarama Modeli” kullanılmıştır. Araştırmanın örneklemini ise basit seçkisiz örnekleme yöntemiyle seçilen 309 (196 erkek ve 113 kadın) katılımcı oluşturmaktadır.

\section{Veri Toplama Aracı}

Kişisel bilgi formu içerisinde cinsiyet, yaş, gelir düzeyi, sınıf ve rekreatif faaliyetlere katılma durumu gibi değişkenlerden oluşmaktadır.

Boş zaman yönetiminin değerlendirilmesinde Wang, Kao, Huan ve Wu (2011) tarafindan geliştirilen ve Türkçe uyarlaması Akgül ve Karaküçük (2015) tarafindan yapılan "Boş Zaman Yönetimi Ölçeği (BZYÖ)” kullanılmıştır. 15 maddeden oluşan ölçek 5'li Likert tipi (1= Hiç Katılmıyorum, 5= Tamamen Katılıyorum) bir yapıya sahiptir. Ölçme aracı, Amaç belirleme ve yöntem, Değerlendirme, Boş Zaman Tutumu ve Programlama olmak üzere dört alt boyuttan oluşmaktadır. Ölçeğin Cronbach Alpha değeri 0.83 ve test tekrar test güvenirliği ise 0.86 bulunmuştur. Alt boyutlar için ise iç tutarlık katsayıları 0.71-.81 arasında değişmektedir. Ayrıca ölçeğin geçerlik güvenirlik çalışması sonucunda elde edilen bulgular incelendiğinde ölçeğin dört faktörlü olmasının yanısıra tek faktörlü olarak kullanılmasının olanaklı olduğu görülmektedir (Akgül ve Karaküçük, 2015).

Öğrencilerin akademik başarısını etkileyen örgütsel faktörlerin değerlendirilmesinde Memduhoğlu ve Tanhan (2013) tarafından geliştirilen "Öğrencilerin Akademik Başarılarını Etkileyen Örgütsel Faktörler Ölçeği (ÖBEÖFÖ)” kullanılmıştır. Ölçek 5'li Likert tipi olup (1= Hiç Katılmıyorum, 5= Tamamen Katılıyorum) 22 maddeli, öğretim elemanlarının mesleki yeterlilikleri ve uygulamaları, yönetsel hizmetler ve uygulamalar, iletişim, fiziksel ortam ve donanım olarak isimlendirilen dört alt boyut içermektedir. Ölçeğin iç tutarlık kat sayısı 0.92 ve alt boyutlar için ise iç tutarlık katsayıları 0.76-0.90 arasında değişmektedir. Ayrıca ölçeğin geçerlik güvenirlik çalışması sonucunda elde edilen bulgulara göre ölçeğin dört faktörlü olmasının yanısıra tek faktörlü olarak kullanılmasının olanaklı olduğu ifade edilmektedir (Memduhoğlu ve Tanhan, 2013).

\section{Veri Analizi}

Verilerin analizinde; verilerin normalliği gözetilerek katılımcıların demografik özelliklerine göre, boş zaman yönetimi ve akademik başarı düzeyleri arasındaki farklılıkları incelemek amacıyla t-Testi ve ANOVA; değişkenler arasındaki ilişkilerin incelenmesi için ise Pearson Korelasyon testi uygulanmıştır. 
Yaşartürk, F., Akyüz, H., ve Karataş, İ. (2018). Rekreasyon bölümü öğrencilerinin boş zaman yönetimi ile akademik başarılarını etkileyen örgütsel faktörler arasındaki ilişkinin incelenmesi. Spor Bilimleri Araştırmaları Dergisi, 3(2), 233-243.

\section{BULGULAR}

Bu bölümde çalışmaya yönelik tablolara ve yorumlara yönelik bilgiler yer almaktadır.

Tablo 1. Katılımcıların demografik değişkenlere göre tanımlayıcı istatistik sonuçları

\begin{tabular}{|c|c|c|c|c|c|}
\hline Değişkenler & & $\mathbf{N}$ & $\%$ & $\bar{x}$ & $\mathbf{S}$ \\
\hline Yaş & & 309 & & 21.47 & 2.04 \\
\hline Gelir Düzeyi & & 309 & & 2989.39 & 1599.23 \\
\hline \multirow{2}{*}{ Cinsiyet } & Kadın & 113 & 36.6 & & \\
\hline & Erkek & 196 & 63.4 & & \\
\hline \multirow{4}{*}{ Sinıf } & 1. Sinif & 98 & 31.7 & & \\
\hline & 2. Sinif & 69 & 22.3 & & \\
\hline & 3. Sinif & 70 & 22.7 & & \\
\hline & 4. Sinif & 72 & 23.3 & & \\
\hline \multirow{2}{*}{$\begin{array}{l}\text { Rekreatif Faaliyetlere } \\
\text { Katılma Durumu }\end{array}$} & Evet & 273 & 88.3 & & \\
\hline & Hayır & 36 & 11.7 & & \\
\hline
\end{tabular}

Katılımcıların yaş ortalamaları 21,47; gelir düzeyleri ise aylık olarak 2989,39 TL olarak belirlenmiştir. Katılımcıların yüzde \%36,6'sını kadın, \%63,4'ünü erkek öğrenciler oluşturmaktadır. Öğrencilerin \%31,7'si 1. sınıf, 22,3'ü 2. sınıf, 22,7'si 3. sinıf ve 23,3'ü 4. sınıfta eğitim görmektedir. Rekreasyon bölümü öğrencilerinin 88,3 'ü rekreatif faaliyetlere katıldığını belirtirken, 11,7'si rekreatif faaliyetlere katılmadığını belirtmiştir.

Tablo 2. Katılımcıların cinsiyet değişkenine yönelik bağımsız iki örnek t-testi sonuçları

\begin{tabular}{|c|c|c|c|c|c|c|c|}
\hline Boyutlar & Cinsiyet & $\mathbf{N}$ & $\mathbf{X}$ & Ss & $\mathbf{t}$ & sd & $\mathbf{p}$ \\
\hline \multirow{2}{*}{ Amaç Belirleme ve Yöntem } & Kadın & 113 & 3.46 & .640 & \multirow{2}{*}{.176} & \multirow{2}{*}{307} & \multirow{2}{*}{.860} \\
\hline & Erkek & 196 & 3.45 & .789 & & & \\
\hline \multirow{2}{*}{ Değerlendirme } & Kadın & 113 & 3.71 & .711 & \multirow[b]{2}{*}{.276} & \multirow{2}{*}{307} & \multirow{2}{*}{.783} \\
\hline & Erkek & 196 & 3.69 & .780 & & & \\
\hline \multirow{2}{*}{ Boş Zaman Tutumu } & Kadın & 113 & 4.14 & .738 & \multirow{2}{*}{-.148} & \multirow{2}{*}{307} & \multirow{2}{*}{.883} \\
\hline & Erkek & 196 & 4.15 & .764 & & & \\
\hline \multirow{2}{*}{ Programlama } & Kadın & 113 & 3.21 & 1.017 & \multirow{2}{*}{.697} & \multirow{2}{*}{307} & \multirow{2}{*}{.486} \\
\hline & Erkek & 196 & 3.12 & 1.004 & & & \\
\hline \multirow{2}{*}{ BZYÖ } & Kadın & 113 & 3.60 & .481 & \multirow{2}{*}{.412} & \multirow{2}{*}{307} & \multirow{2}{*}{.681} \\
\hline & Erkek & 196 & 3.57 & .533 & & & \\
\hline \multirow{2}{*}{ İletişim } & Kadın & 113 & 3.02 & .845 & \multirow{2}{*}{-2.695} & \multirow{2}{*}{307} & \multirow{2}{*}{$.007 *$} \\
\hline & Erkek & 196 & 3.30 & .897 & & & \\
\hline \multirow{2}{*}{$\begin{array}{l}\text { Yönetsel Hizmetler ve } \\
\text { Uygulamalar }\end{array}$} & Kadın & 113 & 2.99 & .884 & \multirow{2}{*}{-3.093} & \multirow{2}{*}{307} & \multirow{2}{*}{$.002 *$} \\
\hline & Erkek & 196 & 3.29 & .796 & & & \\
\hline \multirow{2}{*}{ Fiziksel Ortam ve Donanım } & Kadın & 113 & 2.61 & 1.080 & \multirow{2}{*}{-3.337} & \multirow{2}{*}{307} & \multirow{2}{*}{$.001 *$} \\
\hline & Erkek & 196 & 3.03 & 1.042 & & & \\
\hline \multirow{2}{*}{$\begin{array}{l}\text { Öğretim Elemanlarının Mesleki } \\
\text { Yeterlilikleri ve Uygulamaları }\end{array}$} & Kadın & 113 & 3.36 & .837 & \multirow{2}{*}{-1.559} & \multirow{2}{*}{307} & \\
\hline & Erkek & 196 & 3.51 & .795 & & & .120 \\
\hline ÖВFÖFÖ & Kadın & 113 & 3.10 & .754 & -2962 & 307 & $003 *$ \\
\hline OBEUFU & Erkek & 196 & 3.35 & .700 & -2.902 & 501 & $.003 \%$ \\
\hline
\end{tabular}

Tabloya göre katılımcıların BZYÖ toplam puan ortalamaları ve alt boyutları, ÖBEÖFÖ toplam puan ortalamaları ve alt boyutları cinsiyet değişkeni açısından incelendiğinde ÖBEÖFÖ toplam puan ortalamasında ve "İletişim", "Yönetsel Hizmetler ve Uygulamalar" ve "Fiziksel Ortam ve Donanım" alt boyutlarında istatistiksel olarak anlamlı bir farklılık tespit 
Yaşartürk, F., Akyüz, H., ve Karataş, İ. (2018). Rekreasyon bölümü öğrencilerinin boş zaman yönetimi ile akademik başarılarını etkileyen örgütsel faktörler arasındaki ilişkinin incelenmesi. Spor Bilimleri Araştırmaları Dergisi, 3(2), 233-243.

edilmiştir $(\mathrm{p}<0,05)$. Ortalama değerler incelendiğinde bu anlamlı farklılığın ÖBEÖFÖ toplam puan ortalamaları, "İletişim", "Yönetsel Hizmetler ve Uygulamalar" ve "Fiziksel Ortam ve Donanım" alt boyutlarında erkek katılımcıların lehine olduğu görülmektedir.

Tablo 3. Katılımcıların yaş ve gelir değişkenlerine göre BZYÖ ve ÖBEÖFÖ korelasyon testi sonuçları

\begin{tabular}{|c|c|c|c|c|c|}
\hline & $\begin{array}{c}\text { Amaç } \\
\text { Belirleme ve } \\
\text { Yöntem } \\
\end{array}$ & Değerlendirme & $\begin{array}{c}\text { Boş Zaman } \\
\text { Tutumu }\end{array}$ & Programlama & BZYÖ \\
\hline Yaş & -.018 & -.041 & -.109 & -.078 & -.084 \\
\hline \multirow[t]{2}{*}{ Gelir } & -.047 & .019 & $.132^{*}$ & -.051 & -.003 \\
\hline & İletişim & $\begin{array}{c}\text { Yönetsel } \\
\text { Hizmetler ve } \\
\text { Uygulamalar }\end{array}$ & $\begin{array}{l}\text { Fiziksel Ortam } \\
\text { ve Donanım }\end{array}$ & $\begin{array}{c}\text { Öğretim } \\
\text { Elemanlarının } \\
\text { Mesleki Yeterlilikleri } \\
\text { ve Uygulamaları }\end{array}$ & ÖBEÖFÖ \\
\hline Yaş & .044 & .077 & .051 & .009 & .051 \\
\hline Gelir & -.005 & .003 & -.002 & .057 & .023 \\
\hline
\end{tabular}

Tablo 3'e göre, “yaş değişkeni ile BZYÖ toplam puan ortalamaları ve alt boyutları, ÖBEÖFÖ toplam puan ortalamaları ve alt boyutları" arasındaki ilişkiyi göstermek için yapılan korelasyon analizi sonucunda herhangi bir anlamlı bir ilişki tespit edilmemiştir ( $>0,05)$. Ayrıca, "gelir değişkeni ile BZYÖ toplam puan ortalamaları ve alt boyutları, ÖBEÖFÖ toplam puan ortalamaları ve alt boyutları" arasındaki ilişkiyi göstermek için yapılan korelasyon analizi sonucunda; BZYÖ "boş zaman tutumu" alt boyutunda istatistiksel olarak düşük düzeyde ve pozitif yönde anlamlı bir ilişki tespit edilmiştir $(\mathrm{p}<0,05)$.

Tablo 4. BZYÖ ve ÖBEÖFÖ ile sınıf değişkenine yönelik ANOVA testi sonuçları

\begin{tabular}{|c|c|c|c|c|c|c|c|}
\hline Boyutlar & $\begin{array}{c}\text { Varyansın } \\
\text { Kaynağı }\end{array}$ & $\begin{array}{l}\text { Kareler } \\
\text { Toplamı }\end{array}$ & sd & $\begin{array}{l}\text { Kareler } \\
\text { Ort. }\end{array}$ & $\mathbf{F}$ & $\mathbf{p}$ & $\begin{array}{c}\text { Anlamlı } \\
\text { Fark }\end{array}$ \\
\hline Amaç Belirleme ve & Gruplar arası & 4.670 & 3 & 1.557 & \multirow{2}{*}{2.896} & \multirow{2}{*}{$.035^{*}$} & \multirow{2}{*}{$2>3 *$} \\
\hline Yöntem & Gruplar içi & 163.935 & 305 & .537 & & & \\
\hline \multirow{2}{*}{ Değerlendirme } & Gruplar arası & 7.005 & 3 & 2.335 & \multirow{2}{*}{4.229} & \multirow{2}{*}{$.006 *$} & \multirow{2}{*}{$2>3 *$} \\
\hline & Gruplar içi & 168.405 & 305 & .552 & & & \\
\hline \multirow{2}{*}{ Boş Zaman Tutumu } & Gruplar arası & 1.521 & 3 & .507 & \multirow{2}{*}{.890} & \multirow{2}{*}{.446} & \multirow{2}{*}{---} \\
\hline & Gruplar içi & 173.643 & 305 & .569 & & & \\
\hline \multirow{2}{*}{ Programlama } & Gruplar arası & 17.301 & 3 & 5.767 & \multirow{2}{*}{5.939} & \multirow{2}{*}{$.001 *$} & \multirow{2}{*}{--- } \\
\hline & Gruplar içi & 296.156 & 305 & .971 & & & \\
\hline \multirow{2}{*}{ BZYÖ } & Gruplar arası & 2.110 & 3 & .703 & \multirow{2}{*}{2.697} & \multirow{2}{*}{$.046^{*}$} & \multirow{2}{*}{$2>3 *$} \\
\hline & Gruplar içi & 79.511 & 305 & .261 & & & \\
\hline \multirow{2}{*}{ İletişim } & Gruplar aras1 & 8.819 & 3 & 2.940 & \multirow{2}{*}{3.833} & \multirow{2}{*}{$.010 *$} & \multirow[t]{2}{*}{$2>3 *$} \\
\hline & Gruplar içi & 233.900 & 305 & .767 & & & \\
\hline Yönetsel Hizmetler ve & Gruplar arası & 7.701 & 3 & 2.567 & \multirow{2}{*}{3.724} & \multirow{2}{*}{$.012 *$} & \\
\hline Uygulamalar & Gruplar içi & 210.221 & 305 & .689 & & & \\
\hline Fiziksel Ortam ve & Gruplar arası & 17.942 & 3 & 5.981 & \multirow{2}{*}{5.415} & \multirow{2}{*}{$.001 *$} & \\
\hline Donanım & Gruplar içi & 336.863 & 305 & 1.104 & & & \multirow{3}{*}{$2>3 *$} \\
\hline \multirow{2}{*}{$\begin{array}{l}\text { Öğretim Elemanlarının } \\
\text { Mesleki Yeterlilikleri ve } \\
\text { Uygulamaları }\end{array}$} & Gruplar arası & 10.693 & 3 & 3.564 & \multirow[b]{2}{*}{5.637} & \multirow[b]{2}{*}{$.001 *$} & \\
\hline & Gruplar içi & 192.829 & 305 & .632 & & & \\
\hline ÖBEÖFÖ & $\begin{array}{l}\text { Gruplar arası } \\
\text { Gruplar ici }\end{array}$ & $\begin{array}{c}7.642 \\
156.389\end{array}$ & $\begin{array}{c}3 \\
305\end{array}$ & $\begin{array}{c}2.547 \\
513\end{array}$ & 4.968 & $.002 *$ & $3>4 *$ \\
\hline
\end{tabular}


Yaşartürk, F., Akyüz, H., ve Karataş, İ. (2018). Rekreasyon bölümü öğrencilerinin boş zaman yönetimi ile akademik başarılarını etkileyen örgütsel faktörler arasındaki ilişkinin incelenmesi. Spor Bilimleri Araştırmaları Dergisi, 3(2), 233-243.

Tablo 4 incelendiğinde, sınıf değişkeni ile BZYÖ ve ÖBEÖFÖ toplam puan ortalamalarında istatistiksel olarak anlamlı bir ilişki tespit edilmiştir $(p<0,05)$. Sınıf değişkenine göre BZYÖ toplam puanları açısından anlamlı farklılığın 2. sınıf ve 3. sınıf arasında olduğu ve bu farklılığın 2. sınıf öğrencileri lehine olduğu bulunmuştur. ÖBEÖFÖ toplam puanları açısından ise anlamlı farklılık 3. ve 4. sınıf öğrencileri arasındadır ve bu farklılık 4. sınıf öğrencilerinin lehinedir.

Tablo 5. Katılımcıların rekreatif etkinliklere katılma değişkenine yönelik bağımsız iki örnek t-testi sonuçları

\begin{tabular}{|c|c|c|c|c|c|c|c|}
\hline Değişkenler & $\begin{array}{l}\text { Katılım } \\
\text { Durumu }\end{array}$ & $\mathbf{N}$ & $\mathbf{X}$ & Ss & $\mathbf{t}$ & sd & $\mathbf{p}$ \\
\hline \multirow{2}{*}{ Amaç Belirleme ve Yöntem } & Evet & 273 & 3.5085 & .70835 & \multirow{2}{*}{3.479} & \multirow{2}{*}{307} & \multirow{2}{*}{$.001 *$} \\
\hline & Hayır & 36 & 3.0602 & .85742 & & & \\
\hline \multirow{2}{*}{ Değerlendirme } & Evet & 273 & 3.7497 & .73960 & \multirow{2}{*}{3.156} & \multirow{2}{*}{307} & \multirow{2}{*}{$.002 *$} \\
\hline & Hayır & 36 & 3.3333 & .77664 & & & \\
\hline \multirow{2}{*}{ Boş Zaman Tutumu } & Evet & 273 & 4.1563 & .76322 & \multirow{2}{*}{.407} & \multirow{2}{*}{307} & \multirow{2}{*}{.685} \\
\hline & Hayır & 36 & 4.1019 & .68923 & & & \\
\hline \multirow{2}{*}{ Programlama } & Evet & 273 & 3.1734 & 1.01422 & \multirow{2}{*}{.658} & \multirow{2}{*}{307} & \multirow{2}{*}{.511} \\
\hline & Hayır & 36 & 3.0556 & .97427 & & & \\
\hline \multirow{2}{*}{ BZYÖ } & Evet & 273 & 3.6193 & .50404 & \multirow{2}{*}{3.307} & \multirow{2}{*}{307} & \multirow{2}{*}{$.001 *$} \\
\hline & Hayır & 36 & 3.3222 & .52675 & & & \\
\hline \multirow{2}{*}{ İletişim } & Evet & 273 & 3.2454 & .88017 & \multirow{2}{*}{2.570} & \multirow{2}{*}{307} & \multirow{2}{*}{$.011^{*}$} \\
\hline & Hayır & 36 & 2.8444 & .87650 & & & \\
\hline \multirow{2}{*}{$\begin{array}{l}\text { Yönetsel Hizmetler ve } \\
\text { Uygulamalar }\end{array}$} & Evet & 273 & 3.2187 & .83155 & \multirow{2}{*}{1.819} & \multirow{2}{*}{307} & \multirow{2}{*}{.070} \\
\hline & Hayır & 36 & 2.9484 & .88667 & & & \\
\hline \multirow{2}{*}{ Fiziksel Ortam ve Donanım } & Evet & 273 & 2.8919 & 1.08306 & \multirow{2}{*}{.380} & \multirow{2}{*}{307} & \multirow{2}{*}{.704} \\
\hline & Hayır & 36 & 2.8194 & 1.00820 & & & \\
\hline \multirow{2}{*}{$\begin{array}{l}\text { Öğretim Elemanlarının Mesleki } \\
\text { Yeterlilikleri ve Uygulamaları }\end{array}$} & Evet & 273 & 3.4890 & .80368 & \multirow{2}{*}{1.614} & \multirow{2}{*}{307} & 108 \\
\hline & Hayır & 36 & 3.2569 & .86393 & & & .108 \\
\hline & Evet & 273 & 3.2934 & .72100 & 2083 & 307 & $038 *$ \\
\hline ОВЕОНО & Hayır & 36 & 3.0253 & .76249 & 2.083 & 301 & $.038^{\circ}$ \\
\hline
\end{tabular}

Tabloya göre katılımcıların BZYÖ toplam puan ortalamaları ve alt boyutları, ÖBEÖFÖ toplam puan ortalamaları ve alt boyutları rekreatif faaliyetlere katılma değişkeni açısından incelendiğinde BZYÖ "amaç belirleme ve yöntem", "değerlendirme” alt boyutları ve toplam puan ortalamalarında; ÖBEÖFÖ toplam puan ortalamaları ve "İletişim” alt boyutunda istatistiksel olarak anlamlı bir farklılık tespit edilmiştir $(\mathrm{p}<0,05)$. Ortalama değerler incelendiğinde anlamlı farklılık tespit edilen alt boyutlar ve toplam puan ortalamalarında bu anlamlı farklılı̆̆ın "rekreatif faaliyetlere katılan" katılımcı grubunun lehine olduğu görülmektedir. 
Yaşartürk, F., Akyüz, H., ve Karataş, İ. (2018). Rekreasyon bölümü öğrencilerinin boş zaman yönetimi ile akademik başarılarını etkileyen örgütsel faktörler arasındaki ilişkinin incelenmesi. Spor Bilimleri Araştırmaları Dergisi, 3(2), 233-243.

Tablo 6. Katılımcıların gelir değişkenine göre BZYÖ ve ÖBEÖFÖ korelasyon testi sonuçları

\begin{tabular}{cccccc}
\hline & $\begin{array}{c}\text { Amaç Belirleme } \\
\text { ve Yöntem }\end{array}$ & Değerlendirme & $\begin{array}{c}\text { Boş Zaman } \\
\text { Tutumu }\end{array}$ & Programlama & BZYÖ \\
\hline Gelir & -.047 & .019 & $.132^{*}$ & -.051 & -.003 \\
\hline İletişim & $\begin{array}{c}\text { Yönetsel } \\
\text { Hizmetler ve } \\
\text { Uygulamalar }\end{array}$ & $\begin{array}{c}\text { Fiziksel Ortam } \\
\text { ve Donanım }\end{array}$ & $\begin{array}{c}\text { Öğretim } \\
\text { Elemanlarının } \\
\text { Mesleki } \\
\text { Yeterlilikleri ve } \\
\text { Uygulamaları }\end{array}$ & ÖBEÖFÖ \\
\hline Gelir & -.005 & .003 & -.002 & .057 & .023 \\
\hline
\end{tabular}

Tablo 6' da "gelir değişkeni ile BZYÖ toplam puan ortalamaları ve alt boyutları, ÖBEÖFÖ toplam puan ortalamaları ve alt boyutları" arasındaki ilişkiyi göstermek için yapılan korelasyon analizi sonucu verilmiştir. BZYÖ "boş zaman tutumu" alt boyutunda istatistiksel olarak düşük düzeyde ve pozitif yönde anlamlı bir ilişki tespit edilmiştir $(p<0,05)$.

Tablo 7. Katılımcıların BZYÖ ve ÖBEÖFÖ korelasyon testi sonuçları

\begin{tabular}{cc}
\hline Ölçekler & ÖBEÖFÖ \\
\hline BZYÖ & $.234^{*}$ \\
\hline
\end{tabular}

$\%(\mathrm{p}<0,05)$.

Tablo 7'de, "BZYÖ ve ÖBEÖFÖ toplam puan ortalamaları" arasındaki ilişkiyi göstermek amacıyla yapılan pearson korelasyon analizi sonucu verilmiştir. Analiz sonuçlarına göre BZYÖ ve ÖBEÖFÖ arasında düşük düzeyde pozitif yönde anlamlı bir ilişki tespit edilmiştir.

\section{TARTIŞMA ve SONUÇ}

Bu çalışmanın amacı, rekreasyon bölümü öğrencilerinin boş zaman yönetimi ve akademik başarılarını etkileyen örgütsel faktörler arasındaki ilişkinin incelenmesidir.

Cinsiyet değişkenine göre, ÖBEÖFÖ toplam puan ortalamaları ve alt boyutları incelendiğinde ÖBEÖFÖ toplam puan ortalamalarında ve "İletişim", "Yönetsel Hizmetler ve Uygulamalar" ve "Fiziksel Ortam ve Donanım" alt boyutlarında istatistiksel olarak anlaml bir farklılık bulunmuştur $(p<0,05)$. Ortalama değerler incelendiğinde bu anlamlı farklılığın erkek öğrencilerin lehine olduğu görülmektedir. BZYÖ toplam puan ortalamaları ve alt boyutlarında ise anlamlı farklılık tespit edilmemiş, erkek ve kadın öğrencilerin toplam puan ortalamalarında yakın sonuçlar tespit edilmiştir. Fakat Tektaş ve Tektaş (2010) meslek yüksekokulu öğrencilerinin zaman yönetimi ve akademik başarılarını incelemek amacıyla yaptığı çalışmada, akademik başarı ve zaman yönetimini etkin değerlendirmede kadın öğrencilerin lehine bir sonuca ulaşmıştır. Ek olarak Misra ve McKean (2000) tarafindan yapılan çalışmada kadın öğrencilerin erkek öğrencilere göre, daha yüksek zaman yönetimi puan ortalamasına sahip olduğu belirlenmiştir. Yapılan diğer çalışmalarda ise, kadın öğrencilerin zamanı daha verimli ve etkin yönettiği akademik olarak daha başarılı olduğu sonucuna ulaşılmıştır. Macan ve diğerleri (1990) ile Nelson ve Nelson (2003), kadın 
Yaşartürk, F., Akyüz, H., ve Karataş, İ. (2018). Rekreasyon bölümü öğrencilerinin boş zaman yönetimi ile akademik başarılarını etkileyen örgütsel faktörler arasındaki ilişkinin incelenmesi. Spor Bilimleri Araştırmaları Dergisi, 3(2), 233-243.

öğrencilerin zaman yönetiminde daha verimli olduğu ve akademik başarıya ulaşma düzeylerini etkileyerek erkek öğrencilere göre daha başarılı olduğu sonucuna ulaşmıştır.

Yaş değişkeni göre, BZYÖ toplam puan ortalamaları ve alt boyutları, ÖBEÖFÖ toplam puan ortalamaları ve alt boyutları arasındaki ilişkiyi göstermek için yapılan korelasyon analizi sonucunda herhangi bir anlamlı bir ilişki tespit edilmemiştir ( $>>0,05)$. Rekreasyon bölümü öğrencilerinin, öğrenim şartlarına göre birbirine yakın yaşlarda olması boş zaman yönetimi ve akademik başarı düzeylerinin yaş değişkenine göre benzer olduğunu söyleyebiliriz.

Gelir değişkeni göre, BZYÖ toplam puan ortalamaları ve alt boyutları, ÖBEÖFÖ toplam puan ortalamaları ve alt boyutları arasındaki ilişkiyi göstermek için yapılan korelasyon analizi sonucunda; BZYÖ "boş zaman tutumu" alt boyutunda istatistiksel olarak düşük düzeyde pozitif yönde anlamlı bir ilişki tespit edilmiştir $(p<0,05)$. Öğrencilerin gelir düzeylerinin artması ile birlikte boş zaman tutumlarının bilişsel, duyuşsal ve davranışsal açıdan olumlu yönde değişeceği gibi gelir düzeyi artan öğrencilerin kendine daha fazla boş zaman süresi yaratma olanağının boş zaman tutumu üzerinde etkili olabileceği söylenebilir.

Sınıf değişkeni göre, BZYÖ ve ÖBEÖFÖ toplam puan ortalamalarında incelendiğinde istatistiksel olarak anlamlı bir farklılık tespit edilmiştir $(p<0,05)$. Sınıf değişkenine göre BZYÖ toplam puanları açısından anlamlı farklılığın 2. sınıf ve 3. sınıf arasında olduğu ve bu farklılığın 2. sınıf öğrencilerinin lehine olduğu bulunmuştur. ÖBEÖFÖ toplam puanları açısından ise anlamlı farklılık 3. ve 4. sınıf öğrencileri arasındadır ve bu farklılık 4. sınıf öğrencilerinin lehinedir. Bu durum 4. sınıf öğrencilerinin 3. sınıf öğrencilerine göre okul ve yaşam tecrübelerinin daha fazla olmasıyla mezuniyet sonrası meslek bilincine ulaşmaları akademik başarıdaki farklılık nedeni olarak açıklanabilir.

Rekreatif etkinliklere katılma değişkenine göre, BZYÖ toplam puan ortalamaları ve alt boyutları, ÖBEÖFÖ toplam puan ortalamaları ve alt boyutları incelendiğinde BZYÖ "amaç belirleme ve yöntem", "değerlendirme" alt boyutları ve toplam puan ortalamalarında; ÖBEÖFÖ toplam puan ortalamaları ve "iletişim" alt boyutunda istatistiksel olarak anlamlı bir farklılık bulunmuştur $(\mathrm{p}<0,05)$. Bu sonuca göre ortalama değerler incelendiğinde anlamlı farklılığın "rekreatif faaliyetlere katılan" katılımcı grubunun lehine olduğu görülmektedir. Rekreatif faaliyete katılan öğrencilerin katılmayan öğrencilere göre faaliyet açısından daha iyi amaç ve yöntem belirleyip değerlendirme yaptığı ve iletişim becerilerinin daha güçlü olduğu söylenebilir. Bu durumun rekreatif faaliyetlere katılan öğrencilerin lehine olması, rekreatif faaliyetlerin özgürlük hissi veren, haz ve neşe sağlayan, kişinin kendini ifade edebilmesi ve yaratıcı olabilmesine imkân sağlayan pek çok olumlu özelliği içermesi gruplar arasındaki farklılığın nedeni olarak açıklanabilir.

BZYÖ ve ÖBEÖFÖ toplam puan ortalamaları arasındaki ilişkiyi göstermek için yapılan korelasyon analizi sonucunda istatistiksel olarak düşük düzeyde ve pozitif yönde anlamlı bir ilişski tespit edilmiştir $(p<0,05)$. Rekreasyon bölümü öğrencilerinin boş zaman yönetim düzeyleri arttıkça akademik başarılarını etkileyen örgütsel faktör düzeylerinin de arttığ söylenebilir. Çalışmamıza ek olarak, üniversite öğrencilerinin akademik başarı ve zaman 
Yaşartürk, F., Akyüz, H., ve Karataş, İ. (2018). Rekreasyon bölümü öğrencilerinin boş zaman yönetimi ile akademik başarılarını etkileyen örgütsel faktörler arasındaki ilişkinin incelenmesi. Spor Bilimleri Araştırmaları Dergisi, 3(2), 233-243.

yönetimi becerileri arasındaki ilişkiyi incelemek amacıyla yapılan araştırmalarda ise, zamanı daha verimli kullanan öğrencilerin akademik başarıları da yüksek olduğu sonucu bulunmuştur (Britton \& Tesser, 1991; Macan ve diğ. 1990; Nelson ve Nelson, 2003). Üniversite öğrencilerinin eğitim-öğretim hayatında edindiği bilgi düzeyi onların zaman yönetimi konusunda daha başarılı olmalarını sağlamaktadır. Ayrıca Rekreasyon bölümü öğrencilerinin bu alanda çeşitli dersler alarak kendini geliştirmeleri zaman yönetiminin akademik başarı üzerinde olumlu yönde etki etmesini desteklediğini söyleyebiliriz.

Sonuç olarak; katılımcıların boş zaman yönetimi ve akademik başarı düzeylerinin cinsiyet, sınıf, rekreatif etkinliklere katılma gibi değişkenlere göre farklılık gösterdiği; BZYÖ ve ÖBEÖFÖ arasında pozitif yönde düşük düzeyde bir ilişkinin olduğu sonucuna ulaşılmıştır. $\mathrm{Bu}$ yüzden katılımcıların boş zaman yönetimini olumlu ve doğru bir şekilde uygulaması akademik başarı düzeylerinin de olumlu yönde artacağı söylenebilir.

\section{Öneriler}

- Rekreasyon bölümü öğrencilerinin zaman yönetimi konusunda eğitim ve seminer gibi programlara dâhil olmalarını sağlamak derslerinde ve akademik hedeflerine yönelik başarılarını arttırabilir.

- Rekreasyon bölümü öğrencilerinin, rekreatif faaliyetlere yönelik önemin zaman yönetimindeki etki düzeyi hakkında bilgilendirilmeleri arttırılmalıdır.

- Rekreasyon bölümü öğrencileri ve diğer üniversite öğrencileri açısından gelir düzeyi önemli bir kavram olduğundan, verimli kullanımları ve teşvik edici faktörlerin arttırılması değerli olacaktır.

- Zaman yönetiminin akademik başarı üzerinde göz ardı edilemeyecek düzeyde etkisi olduğundan, akademik başarıyı etkileyecek farklı ölçeklerle bilimsel çalışmalar arttırılmalidir.

\section{KAYNAKLAR}

Adair, J. (2006). Etkili zaman yönetimi. (Çev. Ö. Çolakoğlu). İstanbul: Babıali Kültür.

Ahmann, J. S., \& Glock, M. D. (1971). Evaluating pupil growth: principles of tests and measurement (fourth edition). Boston: Allyn and Bacon Inc.

Akgül, B. M., \& Karaküçük, S. (2015). Boş zaman yönetimi ölçeği: Geçerlik- güvenirlik çalışması. International Journal of Human Sciences, 12(2), 1867-1880.

Bloom, B. S. (1979). Insan nitelikleri ve okulda öğrenme (Çev. Durmuş Ali Özçelik). Ankara: Milli Eğitim Basımevi.

Britton, B.K. \& Tesser, A. (1991). Effects of time management practices on college grades. Journal of Educational Psychology, 83(3), 405-410.

Can, G. (1992). Akademik başarısızlık ve önlenmesi. Eskişehir: Anadolu Üniversitesi Yayınları No: 550.

Carter, V., \& Good, E. (1973). Dictionary of education (fourth edition). New York: McGraw Hill Book Company.

Jersild, A. T. (1983). Çocuk psikolojisi. Çev. Gülseren Günçe. Ankara: Ankara Üniversitesi Eğitim Bilimleri Fakültesi Yayınları No: 4. 
Yaşartürk, F., Akyüz, H., ve Karataş, İ. (2018). Rekreasyon bölümü öğrencilerinin boş zaman yönetimi ile akademik başarılarını etkileyen örgütsel faktörler arasındaki ilişkinin incelenmesi. Spor Bilimleri Araştırmaları Dergisi, 3(2), 233-243.

Julian, C. \& Stanley, K. D. (1972). Educational and psychological measurement and evaluation. New Jersey: Prentice-Hall Inc.

Karaküçük, S. (2008). “Rekreasyon” boş zamanları değerlendirme. Ankara: Gazi Kitabevi.

Macan, T., Shahani, C., Dipboye, Robert L. D., \& Phillips, A. P. (1990). College students time management: correlation with academic performance and stress. Journal of Educational Psychology, 82(4), 760-768.

Memduhoğlu, H. B., \& Tanhan, F. (2013). Üniversite öğrencilerinin akademik başarılarını etkileyen örgütsel faktörler ölçeğinin geçerlik ve güvenirlik çalışması, YYÜ Ĕgitim Fakültesi Dergisi (YYU Journal of Education Faculty), 10(1), 106-124.

Misra, R., \& Mckean, M. (2000). College students' academic stress and its relation to their anxiety, time management, and leisure satisfaction. American Journal of Health Studies, 16(1), 41-45.

Nelson, D. B., \& Nelson, K. W. (2003). Emotional intelligence skills: Significant factors in freshmen achievement and retention. Paper Presented at the American Counselling Association Conference, Anaheim, CA.

Sabuncuoğlu, Z., Paşa, M., \& Kaymaz, K. (2010). Zaman yönetimi. İstanbul: Beta Yayıncılık.

Sayan İ. (2005). Yönetici hemşirelerde zaman yönetimi. Yüksek Lisans Tezi, Marmara Üniversitesi, İstanbul.

Tektaş M., \& Necla, T. (2010). Meslek yüksekokulu öğrencilerinin zaman yönetimi ve akademik başarıları arasındaki ilişki. Selçuk Üniversitesi Sosyal Bilimler Enstitüsü Dergisi, 23, 221-229.

Wang, W.C., Kao C.H., Huan, T. C., \& Wu, C.C. (2011). Free time management contributes to better quality of life: a study of undergraduate students in Taiwan. Journal of Happiness Studies, 12(4), 561- 573.

Wolman, B. B. (1973). Victims of success: Emotional problems of executives. New York: Quadrangle. 